University of Nebraska - Lincoln DigitalCommons@University of Nebraska - Lincoln

Faculty Publications: Department of Entomology

Entomology, Department of

3-10-1893

\title{
Notes on the Wing-Color of North American Locusts Belonging to the Sub-Family Oedipodinæ and Its Seeming Relation to Climatic Conditions.
}

Lawrence Bruner

University of Nebraska

Follow this and additional works at: http://digitalcommons.unl.edu/entomologyfacpub

Part of the Entomology Commons

Bruner, Lawrence, "Notes on the Wing-Color of North American Locusts Belonging to the Sub-Family Edipodinæ and Its Seeming Relation to Climatic Conditions." (1893). Faculty Publications: Department of Entomology. 407.

http://digitalcommons.unl.edu/entomologyfacpub/407

This Article is brought to you for free and open access by the Entomology, Department of at DigitalCommons@University of Nebraska - Lincoln. It has been accepted for inclusion in Faculty Publications: Department of Entomology by an authorized administrator of DigitalCommons@University of Nebraska - Lincoln. 
abundantly a little below the upper shore-line of the ancient Lake Bonneville, and from that point up and down the mountain slopes for several hundreds of feet. Below there are to be found yellow-winged species of Trimerotropis, above red winged Arphias. Blue-winged locusts are also to be met with on the lava beds of the Snake River Plains, on the alkali flats of portions of Montana, Wyoming, Nevada, and California, and in the Coast Range of mountains in southern and Lower (alifornia.

This same variation in wing-color among the representatives of the sub-family was also observed in Mexico, where the writer had an opportunity of visiting a number of different regions from which specimens were secured. The dry interior contained most yellow-winged and the humid "tierra calientes" furnished most red-winged species; while the midway mountain regions were the characteristic home for a blue-winged locust.

The following species are found with both red and yellow wings, viz.; Hippiscus tuberculatus, the prevailing color red, but in the Big Horn Mountains of Wyoming yellow-winged specimens are not uncommon. Hippiscus, here in Nebraska, seems to furnish about an equal number of specimens of each color. A couple of others of the genus are know to have the same wing variations. Psinidia sucerata in the East is normally red-winged, but in the West is yellow-winged. Two of our Arphias, at least, have either red or yellow wings, while Trachyrhachis pardalina may be either the one or the other - the red being most common eastward and the yellow-winged westward upon the plains, and red again in the Sierra Nevadas.

So characteristic does this variation in color of the hind wings of these insects appear, that I have about come to the conclusion that an examination of a fair representative collection of these insects would be a sufficient index of the climate of the region from where they came. Possibly I may be wrong. If so, I would be pleased to hear the views of others who have made this

NOTES ON THE WING-COLOR OF NORTH AMERICAN feature more of a study than I have.

\section{LOCUSTS BELONGING TO THE SUB-FAMILY CEDIPO. DIN $\&$ AND ITS SEEMING RELATION TO CLIMATIC CONDITIONS}

BY LAWRENCE BRUNER, STATE UNIVERSITY, LINCOLN, NEB.

ONE of the many features that have been noted in the study of our North American locusts during the past ten or a dozen years is the color-variation of the wings of the different species of 1ocusts of the sub-family Edipodinæ. As all students know who have had anything to do with these insects, some have yellow, others orange, still others red, and a very few have their wings blue. While this is true, perhaps it has not been generally noted that the presence or absence of humidity seems to have some influence upon these color-variations in the different representatives of this group that are to be met with throughout the country. That such must be the case, I think there can be no doubt. But little investigation is necessary to show that along the Atlantic slopes and even in the interior of the continent as far westward as the eastern edge of the great plains, red or orange is the characteristic color. On the plains and in other arid districts of the west and southwest the red and orange give place almost entirely to yellow. In the mountains red re appears, while at a certain elevation and under peculiar conditions blue takes the place of both. In some species we find both red-and yellow-winged individuals. There are also those in which yellowand blue-winged individuals occur. Nor are these wing-color variations confined strictly to special genera. We find both the red and yellow appearing in species of Arphia, Hippiscus, Derotmema, Trachyrhachis, Psinidia, Lactista, Tomonotus, Dissosteira, etc.; while the blue and yeliow are common to representatives of Leprus and Trimerotropis.

We find the red-winged species most common in humid regions, the yellow-winged in more or less arid regions. In the United States the blue-winged forms are found chiefly in mountainous regions just between the dry and wet conditions. At Pueblo, Colorado, Leprus wheeleri occurs with either blue or yellow wings. Near Ogden and Salt Lake City are found both this species and Trimerotropis cyaneipennis. They occur most 